\title{
sciendo
}

DOI 10.2478/sbe-2020-0052

SBE no. 15(3) 2020

\section{ORGANIZATIONAL CULTURE AND JOB SATISFACTION AMONG UNIVERSITY PROFESSORS IN THE SELECTED CENTRAL AND EASTERN EUROPEAN COUNTRIES}

\section{PAVLOVIĆ NEBOJŠA}

University of Kragujevac, Faculty of Hotel Management and Tourism, Serbia

\section{IVANIŠ MARIJA}

University of Rijeka, Faculty of Tourism and Hospitality Management, Croatia

\section{ČRNJAR KRISTINA}

University of Rijeka, Faculty of Tourism and Hospitality Management, Croatia

\begin{abstract}
:
Organizational culture and job satisfaction are the most important factors for any university. Research into how satisfied professors are with university culture is crucial in finding ways to increase job satisfaction in the present as well as the future. The aim of our study is to investigate whether the type of organizational culture has any effect on job satisfaction and whether there are any differences between Serbia, Slovenia, and Bosnia and Herzegovina. The study was conducted on 489 professors at universities and colleges in Serbia, Slovenia, and Bosnia and Herzegovina. The study shows that university professors in the three investigated countries have a moderate level of job satisfaction. The case study method was used. The data collection technique applied was a survey conducted among university professors. The survey was conducted electronically, via Google Forms, and the key instrument was a questionnaire. The data were processed using SPSS Statistics 21. The results of the study show that improving perceived organizational support can increase the level of job satisfaction of university professors. It is also very important to emphasize the importance and originality of this study since similar studies have not been conducted before in the three countries mentioned.
\end{abstract}

Key words: Organizational culture, job satisfaction, behavioral norms, university professor

\section{Introduction}

The most important prerequisite for a positive and productive business is employee satisfaction with the workplace, especially when it refers to university professors (Behzadi et al. 2012). In general, job satisfaction is not only important for the well-being of workers, but also for the organizational culture. Meeting the main goals set by leaders and individuals in organizations can only be achieved if there is job satisfaction (Salanova et al. 
2010). Robbins and Coulter (2005) describe organizational culture as the mutual values, attitudes, or perceptions held by employees within an organization or organizational part.

Bearing in mind that organizational culture reflects the values, beliefs, and behavioral norms that are used by employees in an organization to give sense to the situations that they come across, it can influence the attitudes and behavior of the employees (Scott-Findlay 2006). Consideration of the core values of an organization may halt potential internal divergence (Watson et al. 2005), which is the main reason behind our research regarding these academic issues.

Harrison (1972) suggested that there are four main types of organizational cultures: power culture, task culture, role culture, and person culture. The power culture has a single source of power from which influence spreads throughout the organization. The structure of a power culture may be seen as a web with control exercised from the center. To be effective, power culture depends on trust and personal communication. Resources and charisma are the main bases for authority. Individuals are encouraged to perform their tasks with few questions asked. There are few rules and very little bureaucracy.

The task culture is one in which power is diffused and based on expertise rather than on position or charisma. Task culture is a team culture that focuses on accomplishing the job in hand. The organizing principles in this culture are flexibility, adaptability, individual autonomy, and mutual respect. On the other hand, a role culture is bureaucracy. The strength of a role culture lies in its specialties or functions (maintenance, production, purchasing, marketing, and so forth). Rules and procedures, as well as job descriptions, dominate the environment of this culture. The main problem with this type of culture is that it can be slow to recognize and respond to change. Finally, the person culture exists solely for the individuals who comprise it. It develops when a group of people decides that it is in their best interest to organize on a collective basis rather than on an individual basis. This is often the case with doctors and lawyers. According to the literature, organizational culture has been investigated from different aspects in the academic environments (Du et al. 2010; Guan et al. 2014).

Most studies show that one of the most important aspects of organizational culture is that it is tied to the job satisfaction of faculty members (Khalid et al. 2012). The job satisfaction of university professors is a complicated subject that is difficult to define or predict (Bolliger and Wasilik 2009) and, according to the literature, it is dependent on gender, age, and years of experience (Bellou, 2010; Klassen et al. 2010; Aydin et al. 2012). In the current study, job satisfaction refers to the satisfaction of university professors with nine different factors relating to their jobs and employment in an educational institute. Job satisfaction is frequently of interest to researchers, considering the significant role it plays in human resources management (Cameron 1978; Trivellas et al. 2009).

University professors are considered the best example of social mobility because they have an unlimited duty to educate young people (Syed et al. 2012). According to previous studies, employees who are satisfied with their jobs are creative, innovative, and initiate innovations that can raise their job performance (Usop et al. 2013). On the other 
hand, dissatisfied professors can become nervous and irritable, which can lead to their incompetence but also to other negative influences in the educational process.

\section{Literature overview}

The relationship between organizational culture and job satisfaction is very significant and there is a great deal of literature dealing with this topic. This type of relationship is very important in any society and especially in the domain of higher education. Aoms and Weathington (2008) investigated the influence of organizational culture on job satisfaction in professors at the University of Tennessee at Chattanooga. The results showed that an organization with a strong and suitable culture positively affects not only the satisfaction of the employees but also the job commitment of the employees with the organization. In their research conducted on business professionals in Taiwan, Chang and Lee (2007) highlighted the importance of a group-oriented culture in organizations in increasing employee job satisfaction. The results showed a positive relationship between the culture of an organization and job satisfaction. According to a study conducted by Janićijević (2008), the main factors of job satisfaction are the nature of the job, a reward system, working conditions, co-workers, and organizational structure (Janićijević 2008). According to Drucker, there are no good or bad jobs; it all comes down to what employees make of it (Drucker 2007). The job satisfaction of faculty professors is a complex subject that is difficult to describe or calculate (Bolliger et al. 2009).

This research postulates that organizational culture has a great influence on job satisfaction among academic staff, thus best illustrating the quality of the educational program. Hence, this study focuses in particular on the ways that the established organizational culture of the 'new institution' impacts the job satisfaction of academic professionals. To our knowledge, many studies have been conducted about the relationships between organizational culture and job satisfaction in university institutes (Yuan et al. 2006; Zamini et al. 2009).

The implementation of the Bologna process has had the greatest influence on the position of professors in all three countries covered in our study. For example, some authors have stated that the transformation of the power relations within a higher education institution and the emergence of new social entities within it, in a new social and educational context, become a significant new force that influences the different aspects, ultimate direction, and form of the teaching process (Janković and Jarić 2009). Generally, university professors have a very significant place in society and society structures and exert an important influence on the educational system (Jarić 2009). Namely, they are identified as the basic postulates of higher education, directly affecting the general educational standards of society. Over the last three decades, there have been wideranging political and economic changes in many East European countries, including Serbia and Bosnia and Herzegovina. These two countries have experienced war, economic blockades, hyper-inflation (Hanke and Krus 2012, 12), NATO bombing, and political, economic, and social changes, all of which have left extensive consequences. It has not yet been determined, however, what effect these factors have had on organizational culture and the job satisfaction of university professors. Because of all these 
developments, university professors in these countries might be more dissatisfied with their jobs and their status.

If we explore the cultures of Serbia, Slovenia, and Bosnia and Herzegovina through Hofstede's 6D model, we can see the drivers of culture in these countries compared with other world cultures (www.hofstede-insights.com):

- Power Distance Index (PDI) - When it comes to this dimension that deals with the fact that not all individuals in societies are equal, Serbia and Slovenia have high indexes of 86 and 71, respectively, indicating that people accept hierarchy in organizations as well as centralization, while Bosnia and Herzegovina is a country of inequality, with relatively a large range of powers.

- Individualism versus Collectivism (IDV) - This dimension addresses the issue of interdependence among members of society. In individualistic societies, people are concerned with themselves and their families. Studies conducted by Hofstede in over 50 countries indicate that the countries of the former Yugoslavia are characterized as collectivist societies. Loyalty to the collectivist culture is paramount and overrides most other social rules and regulations.

- Masculinity versus Femininity (MAS) - In this dimension, a high score (Masculine) shows that society is driven by competition, achievement, and success, with success being defined by the winner. A low score indicates a Feminine society in which quality of life is a sign of success, and standing out from the crowd is frowned on. Serbia is considered a relatively Feminine society, where the focus is on "working to live", managers strive for consensus, and people value equality, solidarity, and quality in their working lives. Conflicts are resolved through compromise and negotiation. Leisure and flexibility are supported. Slovenia also belongs to a Feminine society, while Bosnia and Herzegovina is a country dominated more by men than by women, although women are beginning to change this and are the driving force behind change.

- Uncertainty Avoidance Index (UAI) - This dimension has to do with how society deals with the fact that the future can never be known. Serbia, Slovenia, and Bosnia and Herzegovina have a fairly high level of uncertainty avoidance. In these cultures, there is an emotional need for rules, time is money, people have an inner urge to be busy and work hard, precision and accuracy are the norms, and innovation can be resisted.

- Long Term Orientation versus Short Term Normative Orientation (LTO) - This dimension describes how each society must maintain some connections with its past, addressing the challenges of the present and future, and societies differently favor these two existential goals. Serbia, Slovenia, and Bosnia and Herzegovina do not have a clear preference for this dimension.

- Indulgence versus Restraint (IVR) - This dimension is defined as the degree to which people try to control their desires and urges, based on the way they were raised. Relatively weak control is called "Indulgence" and relatively strong control, "Restraint". Cultures can, therefore, be described as indulgent or restrained. The cultures of the three studied countries are restrained. 
As a consequence of the rapid development of higher education and the increase in enrollment in universities, competition is becoming increasingly intense between colleges or universities. Because of this, university professors in Serbia, Slovenia, and Bosnia and Herzegovina are confronted with increased workloads and could feel major pressure from education, research, publishing academic papers and professional position assessments. According to Alas and Vadi (2004), it is easier to change the technology and structures of a company in developing countries than the culturally incorporated practices in transitional countries (Alas et al. 2004). Considering all the social and educational changes that have been made in Serbia, Bosnia and Herzegovina, and Slovenia, our study aimed to investigate the following:

1. Is there any significant relationship between types of organizational culture and the job satisfaction of faculty professors in Serbia, Bosnia and Herzegovina, and Slovenia?

2. Are there any significant differences in types of organizational cultures and job satisfaction between professors in Serbia, Bosnia and Herzegovina, and Slovenia?

3. Which type of organizational culture is a stronger predictor for the job satisfaction of faculty professors in those three countries?

\section{Methodology}

Respondents and data collection. Research lasted one month and was carried out from 1st March to 1st April 2018. During this period questionnaires were collected by interviewing respondents. Responses were received from 489 university professors, of which 212 (43.4\%) in Serbia, 151 (30.9\%) in Slovenia, and 126 (25.8\%) in Bosnia and Herzegovina. The average age of the respondents in Serbia was $45.18 \pm 10.71$; in Slovenia, $48.83 \pm 9.99$; and in Bosnia and Herzegovina, $43.41 \pm 9.28$. The average total work experience of respondents in our study was $19.58 \pm 10.36$ years, while the working experience at the current employer was $14.93 \pm 8.96$ years. For respondents in Serbia, the average total work experience was $19.12 \pm 10.45$ years and at the current employer, 15.08 \pm 9.47 years. Similar results were confirmed for professors in Slovenia, where the average total work experience was $22.59 \pm 10.46$ years and at the current employer, $15.08 \pm 9.47$ years. For professors in Bosnia and Herzegovina the average total work experience was 16.80 years $(S D=9.20)$, and at the current employer, 12.97 years $(S D=7.07)$. In all three countries the distribution of professors according to gender was very uniform (Table 1 ).

Table 1. Distribution of professors according to gender

\begin{tabular}{|c|c|c|c|c|c|c|c|c|}
\hline & \multicolumn{2}{|c|}{ Whole sample } & \multicolumn{2}{c|}{ Serbia } & \multicolumn{2}{c|}{ Slovenia } & \multicolumn{2}{c|}{$\begin{array}{c}\text { Bosnia and } \\
\text { Herzegovina }\end{array}$} \\
\hline & $\mathrm{f}$ & $\%$ & $\mathrm{f}$ & $\%$ & $\mathrm{f}$ & $\%$ & $\mathrm{f}$ & $\%$ \\
\hline Male & 244 & 49.9 & 104 & 49.1 & 75 & 49.7 & 65 & 51.6 \\
\hline Female & 245 & 50.1 & 108 & 50.9 & 76 & 50.3 & 61 & 48.4 \\
\hline$\Sigma$ & 489 & & 212 & & 151 & & 126 & \\
\hline
\end{tabular}

Research instruments. The Job Satisfaction Survey (JSS), which measures the job satisfaction of employees, was used in this study. The job satisfaction questionnaire 
consists of 36 items, rated on a scale of 1 to 6 , and nine scales, rating the attitudes of employees about the job and its aspects: salary, promotion, supervision, benefits, rewards, operation procedures, co-workers, the nature of the job, and communication (Spector 1985). The significance of each of these scales is different to some extent and the result is indifferent importance in cases of evaluation of total job satisfaction (Spector 1997). Cronbach's alpha for these items equals 0.78 . The second questionnaire focused on examining types of organizational culture. It consisted of 60 questions, rated with a 4-point scale, ranging from "I agree" to "I completely disagree". The themes are grouped around the four types of organizational cultures: Power Culture, Role Culture, Task Culture, and Person Culture. Each type of organizational culture is represented with 15 items. The questionnaire also contains demographic variables that are of interest for research.

Statistical analysis. Data were processed by instruments for measuring organizational culture dimensions and job satisfaction. The internal consistency of scales was confirmed. Descriptive statistics and correlation analysis were performed to analyze the relationship between organizational culture and job satisfaction. The influence of the types of organizational cultures on job satisfaction was examined by multiple linear regressions in which the predicate variables were the types of organizational cultures, and the criterion variable was job satisfaction. A multivariate analysis of variance (MANOVA) was used to test for differences between the three investigated countries with types of organizational cultures and job satisfaction factors. Significance was determined at the $\mathrm{p}<0.05$ level.

\section{Results}

According to our results, a high percentage of professors in all three investigated countries claim that they are satisfied with their jobs (Table 2). Six professors in Serbia claimed they are very dissatisfied with their jobs, relative to one professor in Slovenia and three, in Bosnia and Herzegovina (Table 2).

\section{Table 2. Self-assessment of job satisfaction}

\begin{tabular}{|c|c|c|c|c|c|c|c|c|}
\hline & \multicolumn{2}{|c|}{ Whole sample } & \multicolumn{2}{c|}{ Serbia } & \multicolumn{2}{c|}{ Slovenia } & \multicolumn{2}{c|}{$\begin{array}{c}\text { Bosnia and } \\
\text { Herzegovina }\end{array}$} \\
\hline & $\mathrm{f}$ & $\%$ & $\mathrm{f}$ & $\%$ & $\mathrm{f}$ & $\%$ & $\mathrm{f}$ & $\%$ \\
\hline I am very satisfied & 62 & 12.7 & 32 & 15.1 & 17 & 11.3 & 13 & 10.3 \\
\hline I am satisfied & 249 & 50.9 & 100 & 47.2 & 87 & 57.6 & 62 & 49.2 \\
\hline $\begin{array}{c}\text { I neither satisfied nor } \\
\text { dissatisfied }\end{array}$ & 129 & 26.4 & 51 & 24.1 & 38 & 25.2 & 40 & 31.7 \\
\hline I am not satisfied & 39 & 8.0 & 23 & 10.8 & 8 & 5.3 & 8 & 6.3 \\
\hline I am very dissatisfied & 10 & 2.0 & 6 & 2.8 & 1 & 0.7 & 3 & 2.4 \\
\hline$\Sigma$ & 489 & & 212 & & 151 & & 126 & \\
\hline
\end{tabular}

A multiple regression analysis was carried out to check the impact of the types of organizational cultures on job satisfaction. A linear model was formed in which the types of organizational cultures (Power culture, Role Culture, and People Culture) were the predictor variables, and job satisfaction, the criterion variable. The results of regression analysis indicate that these three predictor variables explain $20 \%(R 2=0.20, F(3.125)=$ 9.95, $p=0.001$ ) of job satisfaction (Table 3 ). 
Table 3. Regression analysis

\begin{tabular}{|c|c|c|c|c|}
\hline Model & $\mathrm{R}$ & $\mathrm{R}$ Square & Adjusted R Square & Std. Error of the Estimate \\
\hline 1 & $.443 a$ & .197 & .177 & 15.90519 \\
\hline
\end{tabular}

Power Culture $(\beta=0.19, \mathrm{t}(125)=2.27, p=0.03)$, Role Culture $(\beta=-0.32, \mathrm{t}(125)$ $=-3.47, p=0.001)$ and People Culture $(\beta=-0.21, \mathrm{t}(1250)=-2.35, \mathrm{p}=0.02)$ significantly predict job satisfaction in university professors from the three investigated countries (Table 4).

Table 4. Impact of organizational culture on job satisfaction

\begin{tabular}{|c|c|c|c|c|c|c|c|c|c|c|c|c|}
\hline \multicolumn{13}{|c|}{ Coefficients } \\
\hline \multirow{2}{*}{ Model } & \multicolumn{2}{|c|}{$\begin{array}{l}\text { Unstandardized } \\
\text { Coefficients }\end{array}$} & \multirow{2}{*}{$\begin{array}{c}\begin{array}{c}\text { Stand } \\
\text { ardize } \\
d \\
\text { Coeffi } \\
\text { cients }\end{array} \\
\text { Beta }\end{array}$} & \multirow{2}{*}{$\mathrm{t}$} & \multirow{2}{*}{ Sig. } & \multicolumn{2}{|c|}{$\begin{array}{c}95.0 \% \\
\text { Confidence } \\
\text { Interval for B }\end{array}$} & \multicolumn{3}{|c|}{ Correlations } & \multicolumn{2}{|c|}{$\begin{array}{l}\text { Collinearity } \\
\text { Statistics }\end{array}$} \\
\hline & B & $\begin{array}{l}\text { Std. } \\
\text { Error }\end{array}$ & & & & $\begin{array}{l}\text { Lower } \\
\text { Bound }\end{array}$ & $\begin{array}{l}\text { Upper } \\
\text { Bound }\end{array}$ & $\begin{array}{l}\text { Zero- } \\
\text { order }\end{array}$ & Partial & Part & Tolerance & VIF \\
\hline (Constant) & 157.204 & 9.815 & & .017 & .000 & 137.774 & 176.633 & & & & & \\
\hline Power Culture & .416 & .183 & 191 & 269 & .025 & .053 & .778 & .115 & 201 & .184 & .925 & 1.081 \\
\hline Role Culture & -.825 & .238 & -.315 & .473 & .001 & -1.295 & -.355 & -.343 & -.300 & -.282 & .801 & 1.248 \\
\hline People Culture & -.442 & .188 & -.206 & .350 & .020 & -.813 & -.070 & -.324 & -.208 & -.191 & .855 & 1.170 \\
\hline & & & & $\mathrm{De}$ & dent & iable: & atisfac & & & & & \\
\hline
\end{tabular}

Correlation analysis. Pearson's coefficients of correlation were used to determine the levels of correlation between OC and JS for university professors in Serbia, Slovenia, and Bosnia and Herzegovina.

Table 5. Correlation between types of organizational cultures and job satisfaction

\begin{tabular}{|c|c|c|c|c|c|}
\hline & & $\begin{array}{c}\text { Job } \\
\text { satisfaction }\end{array}$ & $\begin{array}{l}\text { Power } \\
\text { Culture }\end{array}$ & Role Culture & Task Culture \\
\hline \multirow[t]{2}{*}{ Power Culture } & $r$ & 0.115 & & & \\
\hline & Sig. (2-tailed) & 0.200 & & & \\
\hline \multirow[t]{2}{*}{ Role Culture } & $r$ & $-0.343^{* \star}$ & $0.250^{\star *}$ & & \\
\hline & Sig. (2-tailed) & 0.000 & 0.005 & & \\
\hline \multirow[t]{2}{*}{ Task Culture } & $r$ & $-0.416^{* *}$ & -0.136 & $0.677^{* *}$ & \\
\hline & Sig. (2-tailed) & 0.000 & 0.130 & 0.000 & \\
\hline \multirow[t]{2}{*}{ People Culture } & $r$ & $-0.324^{* *}$ & -0.011 & $0.366^{* *}$ & $0.719^{* *}$ \\
\hline & Sig. (2-tailed) & 0.000 & 0.905 & 0.000 & 0.000 \\
\hline
\end{tabular}

The independent variables are moderately correlated to the dependent variable and the correlation is statistically significant $(p<0.05)$, with the exception of Power Culture where the level of correlation is poorly linked and is not statistically significant. Power Culture is not significantly correlated to Task Culture and People Culture $(p>0.05$, Table 5). Task Culture $(r=-0.416, p<0.001$; Table 5), Role Culture $(r=-0.343, p<0.001$; Table 5) and People Culture $(r=-0.324, p<0.001$; Table 5$)$ are characterized by significant negative levels of correlation. The correlation between Role Culture and Power Culture $(r=0.250$, $p<0.005$; Table 5) is significant and moderate. 


\subsection{Effects of types of organizational cultures (Task Culture excluded) on job satisfaction}

The results of regression analysis indicate that these three predictor variables explain $19 \%(R 2=0.190, F(3.125)=9.68, p=0.00)$ of job satisfaction (Table 6).

Table 6. Regression analysis

\begin{tabular}{|c|c|c|c|c|}
\hline Model & $\mathrm{R}$ & $\mathrm{R}$ Square & Adjusted R Square & $\begin{array}{c}\text { Std. Error of the } \\
\text { Estimate }\end{array}$ \\
\hline 1 & $.438 \mathrm{a}$ & .192 & .172 & 15.94853 \\
\hline
\end{tabular}

Task Culture $(\beta=-0.27, \mathrm{t}(125)=-2.20, \mathrm{p}=0.03)$ significantly predicts job satisfaction. The other two independent variables, Power Culture and Role Culture, do not significantly predict job satisfaction, $\mathrm{p}>0.05$ (Table 7).

Table 7. Prediction of job satisfaction

\begin{tabular}{|c|c|c|c|c|c|c|c|c|c|c|c|c|}
\hline \multirow{2}{*}{ Model } & \multicolumn{2}{|c|}{$\begin{array}{l}\text { Unstandardized } \\
\text { Coefficients }\end{array}$} & \multirow{2}{*}{$\begin{array}{c}\begin{array}{c}\text { Standar } \\
\text { dized } \\
\text { Coeffici } \\
\text { ents }\end{array} \\
\text { Beta }\end{array}$} & \multirow{2}{*}{$\mathrm{t}$} & \multirow{2}{*}{ Sig. } & \multicolumn{2}{|c|}{$\begin{array}{l}95.0 \% \text { Confidence } \\
\text { Interval for B }\end{array}$} & \multicolumn{3}{|c|}{ Correlations } & \multicolumn{2}{|c|}{$\begin{array}{l}\text { Collinearity } \\
\text { Statistics }\end{array}$} \\
\hline & B & $\begin{array}{l}\text { Std. } \\
\text { Error }\end{array}$ & & & & $\begin{array}{l}\text { Lower } \\
\text { Bound }\end{array}$ & $\begin{array}{l}\text { Upper } \\
\text { Boun } \\
\text { d }\end{array}$ & $\begin{array}{l}\text { Zero- } \\
\text { order }\end{array}$ & $\begin{array}{c}\text { Part } \\
\text { ial }\end{array}$ & Part & $\begin{array}{l}\text { Toler } \\
\text { ance }\end{array}$ & VIF \\
\hline $\begin{array}{l}\text { (Constan } \\
\text { t) }\end{array}$ & $\begin{array}{c}154.3 \\
56\end{array}$ & 9.384 & & 16.448 & .000 & 135.779 & $\begin{array}{c}172.9 \\
34 \\
\end{array}$ & & & & & \\
\hline $\begin{array}{l}\text { Power } \\
\text { Culture }\end{array}$ & .274 & 202 & . 126 & 1.359 & .177 & -.125 & .674 & .115 & .122 & .111 & .766 & 1.306 \\
\hline $\begin{array}{l}\text { Role } \\
\text { Culture }\end{array}$ & -.503 & . 328 & -.192 & -1.532 & .128 & -1.152 & .147 & -.343 & $\begin{array}{c}- \\
.137 \\
\end{array}$ & $\begin{array}{c}- \\
.125 \\
\end{array}$ & .422 & 2.369 \\
\hline $\begin{array}{l}\text { Task } \\
\text { Culture } \\
\end{array}$ & -.560 & .255 & -.269 & -2.198 & .030 & -1.064 & -.056 & -.416 & $\begin{array}{c}- \\
.195\end{array}$ & $\begin{array}{c}- \\
.179 \\
\end{array}$ & .442 & 2.262 \\
\hline
\end{tabular}

\subsection{Types of organizational cultures in Serbia, Bosnia and Herzegovina, and Slovenia}

To determine the types of differences in organizational culture between Serbia, Slovenia, and Bosnia and Herzegovina, ANOVA was conducted for each factor separately. The ANOVA tests detected statistically significant differences between professors in Serbia, Slovenia, and Bosnia and Herzegovina in Power Culture $(F(2.485)=3.61, p=$ $0.03)$ and Role Culture $(F(2.485)=3.99, p=0.02)$ (Table 8$)$.

Table 8. Differences between professors in Serbia, Slovenia, and Bosnia and Herzegovina, in four types of organizational cultures

\begin{tabular}{|c|c|c|c|c|c|c|c|}
\hline Source & $\begin{array}{c}\text { Dependent } \\
\text { Variable }\end{array}$ & $\begin{array}{c}\text { Type III Sum } \\
\text { of Squares }\end{array}$ & $\mathrm{df}$ & Mean Square & $\mathrm{F}$ & Sig. & $\begin{array}{c}\text { Partial Eta } \\
\text { Squared }\end{array}$ \\
\hline \multirow{4}{*}{$\begin{array}{c}\text { Corrected } \\
\text { Model }\end{array}$} & $\begin{array}{c}\text { Power } \\
\text { Culture }\end{array}$ & $500.587 \mathrm{a}$ & 2 & 250.294 & 3.613 & .028 & .015 \\
\cline { 2 - 9 } & Role Culture & $498.524 \mathrm{~b}$ & 2 & 249.262 & 3.997 & .019 & .016 \\
\cline { 2 - 9 } & Task Culture & $78.062 \mathrm{c}$ & 2 & 39.031 & .512 & .600 & .002 \\
\cline { 2 - 9 } & $\begin{array}{c}\text { People } \\
\text { Culture }\end{array}$ & $255.651 \mathrm{~d}$ & 2 & 127.825 & 2.138 & .119 & .009 \\
\hline \multirow{4}{*}{ Intercept } & $\begin{array}{c}\text { Power } \\
\text { Culture }\end{array}$ & 600112.565 & 1 & 600112.565 & 8663.034 & .000 & .947 \\
\cline { 2 - 9 } & Role Culture & 530260.769 & 1 & 530260.769 & 8503.665 & .000 & .946 \\
\cline { 2 - 8 } & Task Culture & 582728.257 & 1 & 582728.257 & 7644.915 & .000 & .940 \\
\hline
\end{tabular}




\section{Studies in Business and Economics no. 15(3)/2020}

\begin{tabular}{|c|c|c|c|c|c|c|c|}
\hline & $\begin{array}{l}\text { People } \\
\text { Culture }\end{array}$ & 654358.872 & 1 & 654358.872 & 10946.520 & .000 & .958 \\
\hline \multirow{4}{*}{ Country } & $\begin{array}{l}\text { Power } \\
\text { Culture }\end{array}$ & 500.587 & 2 & 250.294 & 3.613 & .028 & .015 \\
\hline & Role Culture & 498.524 & 2 & 249.262 & 3.997 & .019 & .016 \\
\hline & Task Culture & 78.062 & 2 & 39.031 & .512 & .600 & .002 \\
\hline & $\begin{array}{l}\text { People } \\
\text { Culture }\end{array}$ & 255.651 & 2 & 127.825 & 2.138 & .119 & .009 \\
\hline \multirow{4}{*}{ Error } & $\begin{array}{l}\text { Power } \\
\text { Culture }\end{array}$ & 33597.306 & 485 & 69.273 & & & \\
\hline & Role Culture & 30243.015 & 485 & 62.357 & & & \\
\hline & Task Culture & 36968.783 & 485 & 76.224 & & & \\
\hline & $\begin{array}{l}\text { People } \\
\text { Culture }\end{array}$ & 28992.232 & 485 & 59.778 & & & \\
\hline \multirow{4}{*}{ Total } & $\begin{array}{l}\text { Power } \\
\text { Culture }\end{array}$ & 659796.000 & 488 & & & & \\
\hline & Role Culture & 587617.000 & 488 & & & & \\
\hline & Task Culture & 645958.000 & 488 & & & & \\
\hline & $\begin{array}{l}\text { People } \\
\text { Culture }\end{array}$ & 709287.000 & 488 & & & & \\
\hline \multirow{4}{*}{$\begin{array}{l}\text { Corrected } \\
\text { Total }\end{array}$} & $\begin{array}{l}\text { Power } \\
\text { Culture }\end{array}$ & 34097.893 & 487 & & & & \\
\hline & Role Culture & 30741.539 & 487 & & & & \\
\hline & Task Culture & 37046.844 & 487 & & & & \\
\hline & $\begin{array}{l}\text { People } \\
\text { Culture }\end{array}$ & 29247.883 & 487 & & & & \\
\hline
\end{tabular}

Analysis shows that Slovenia has a more pronounced Power Culture $(M=37.32$, $S D=7.98)$ in comparison with Serbia $(M=35.08, S D=8.70)$ and Bosnia and Herzegovina $(\mathrm{M}=35.22, \mathrm{SD}=8.09)$ (Figure 1$)$.

Figure 1. Differences in Power Culture between Serbia, Slovenia, and Bosnia and Herzegovina $\left({ }^{*}-p<0.05\right)$

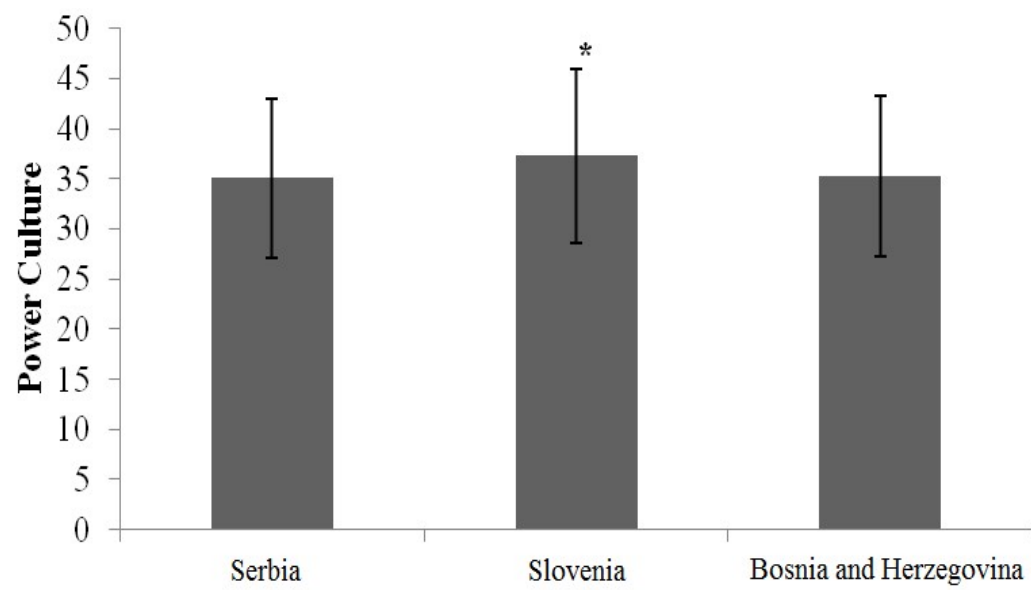

Role Culture $(M=35.09, S D=8.03)$ in Slovenia is also more pronounced, compared with Serbia $(M=33.67, S D=8.44)$ and Bosnia and Herzegovina $(M=32.41$, $\mathrm{SD}=6.69)($ Figure 2) 
Figure 2. Differences in Role Culture between Serbia, Slovenia, and Bosnia and Herzegovina $\left({ }^{*}-p<0.05\right)$

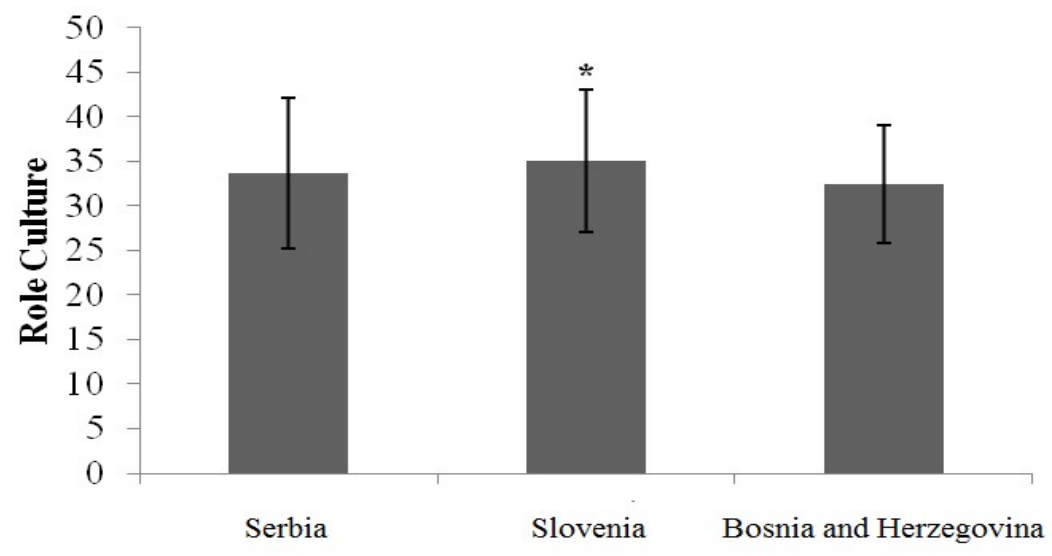

\subsection{Differences between Serbia, Slovenia, and Bosnia and Herzegovina with regard to the dimension of job satisfaction}

Table 9. Differences between Serbia, Slovenia, and Bosnia and Herzegovina in the combination of nine factors of job satisfaction

\begin{tabular}{|c|c|c|c|c|c|c|c|}
\hline \multicolumn{2}{|c}{} & Value & $\mathrm{F}$ & Hypothesis df & Error df & Sig. & $\begin{array}{c}\text { Partial Eta } \\
\text { Squared }\end{array}$ \\
\hline \multirow{5}{*}{ Intercept } & Pillai's Trace & .982 & 2918.506 & 9.000 & 471.000 & .000 & .982 \\
\cline { 2 - 8 } & Wilks' Lambda & .018 & 2918.506 & 9.000 & 471.000 & .000 & .982 \\
\cline { 2 - 8 } & $\begin{array}{c}\text { Hotelling's } \\
\text { Trace }\end{array}$ & 55.768 & 2918.506 & 9.000 & 471.000 & .000 & .982 \\
\cline { 2 - 8 } & $\begin{array}{c}\text { Roy's Largest } \\
\text { Root }\end{array}$ & 55.768 & 2918.506 & 9.000 & 471.000 & .000 & .982 \\
\hline \multirow{5}{*}{ Country } & Pillai's Trace & .262 & 7.900 & 18.000 & 944.000 & .000 & .131 \\
\cline { 2 - 8 } & Wilks' Lambda & .744 & 8.350 & 18.000 & 942.000 & .000 & .138 \\
\cline { 2 - 8 } & $\begin{array}{c}\text { Hotelling's } \\
\text { Trace }\end{array}$ & .337 & 8.801 & 18.000 & 940.000 & .000 & .144 \\
\cline { 2 - 8 } & $\begin{array}{c}\text { Roy's Largest } \\
\text { Root }\end{array}$ & .313 & 16.424 & 9.000 & 472.000 & .000 & .238 \\
\hline
\end{tabular}

Statistical analysis shows significant differences between professors in Serbia and Slovenia with regard to job satisfaction factors such as salary $(F(2.482)=3.13, p=0.04)$, promotion $(F(2.482)=13.37, p=0.00)$, benefits $(F(2.482)=16.61, p=0.00)$, co-workers $(F(2.482)=4.00, p=0.02)$ and the nature of the job $(F(2.482)=3.10, p=0.05)($ Table 10).

Table 10. Differences between Serbia, Slovenia, and Bosnia and Herzegovina in some factors of job satisfaction

\begin{tabular}{|c|c|c|c|c|c|c|c|}
\hline Source & $\begin{array}{l}\text { Dependent } \\
\text { Variable }\end{array}$ & $\begin{array}{l}\text { Type III Sum } \\
\text { of Squares }\end{array}$ & df & Mean Square & $F$ & Sig. & $\begin{array}{l}\text { Partial } \\
\text { Eta } \\
\text { Square } \\
\text { d }\end{array}$ \\
\hline \multirow{3}{*}{$\begin{array}{c}\text { Corrected } \\
\text { Model }\end{array}$} & Salary & 70.658 & 2 & 35.329 & 3.134 & .044 & .013 \\
\hline & Promotion & 257.314 & 2 & 128.657 & 13.372 & .000 & .053 \\
\hline & Supervision & 65.243 & 2 & 32.621 & 2.314 & .100 & .010 \\
\hline
\end{tabular}




\section{Studies in Business and Economics no. 15(3)/2020}

\begin{tabular}{|c|c|c|c|c|c|c|c|}
\hline & Benefits & 339.086 & 2 & 169.543 & 16.614 & .000 & .065 \\
\hline & Reward & 26.543 & 2 & 13.271 & 1.129 & .324 & .005 \\
\hline & $\begin{array}{l}\text { Operation } \\
\text { procedures }\end{array}$ & 23.910 & 2 & 11.955 & 1.580 & .207 & .007 \\
\hline & Co-workers & 71.571 & 2 & 35.785 & 4.009 & .019 & .016 \\
\hline & $\begin{array}{c}\text { The nature of the } \\
\text { job }\end{array}$ & 48.695 & 2 & 24.348 & 3.102 & .046 & .013 \\
\hline & Communication & 22.269 & 2 & 11.135 & 1.146 & .319 & .005 \\
\hline \multirow{9}{*}{ Intercept } & Salary & 69807.117 & 1 & 69807.117 & 6193.456 & .000 & .928 \\
\hline & Promotion & 83211.083 & 1 & 83211.083 & 8648.535 & .000 & .948 \\
\hline & Supervision & 118342.730 & 1 & 118342.730 & 8393.284 & .000 & .946 \\
\hline & Benefits & 81973.566 & 1 & 81973.566 & 8032.633 & .000 & .944 \\
\hline & Reward & 87592.736 & 1 & 87592.736 & 7450.529 & .000 & .940 \\
\hline & $\begin{array}{l}\text { Operation } \\
\text { procedures }\end{array}$ & 92818.193 & 1 & 92818.193 & 12267.604 & .000 & .962 \\
\hline & Co-workers & 107536.995 & 1 & 107536.995 & 12046.895 & .000 & .962 \\
\hline & $\begin{array}{c}\text { The nature of the } \\
\text { job }\end{array}$ & 132172.804 & 1 & 132172.804 & 16837.359 & .000 & .972 \\
\hline & Communication & 118363.449 & 1 & 118363.449 & 12185.106 & .000 & .962 \\
\hline \multirow{9}{*}{ Country } & Salary & 70.658 & 2 & 35.329 & 3.134 & .044 & .013 \\
\hline & Promotion & 257.314 & 2 & 128.657 & 13.372 & .000 & .053 \\
\hline & Supervision & 65.243 & 2 & 32.621 & 2.314 & .100 & .010 \\
\hline & Benefits & 339.086 & 2 & 169.543 & 16.614 & .000 & .065 \\
\hline & Reward & 26.543 & 2 & 13.271 & 1.129 & .324 & .005 \\
\hline & $\begin{array}{l}\text { Operation } \\
\text { procedures }\end{array}$ & 23.910 & 2 & 11.955 & 1.580 & .207 & .007 \\
\hline & Co-workers & 71.571 & 2 & 35.785 & 4.009 & .019 & .016 \\
\hline & $\begin{array}{c}\text { The nature of the } \\
\text { job }\end{array}$ & 48.695 & 2 & 24.348 & 3.102 & .046 & .013 \\
\hline & Communication & 22.269 & 2 & 11.135 & 1.146 & .319 & .005 \\
\hline \multirow{9}{*}{ Error } & Salary & 5398.861 & 479 & 11.271 & & & \\
\hline & Promotion & 4608.655 & 479 & 9.621 & & & \\
\hline & Supervision & 6753.753 & 479 & 14.100 & & & \\
\hline & Benefits & 4888.228 & 479 & 10.205 & & & \\
\hline & Reward & 5631.401 & 479 & 11.757 & & & \\
\hline & $\begin{array}{l}\text { Operation } \\
\text { procedures }\end{array}$ & 3624.173 & 479 & 7.566 & & & \\
\hline & Co-workers & 4275.809 & 479 & 8.927 & & & \\
\hline & $\begin{array}{c}\text { The nature of the } \\
\text { job }\end{array}$ & 3760.137 & 479 & 7.850 & & & \\
\hline & Communication & 4652.901 & 479 & 9.714 & & & \\
\hline \multirow{9}{*}{ Total } & Salary & 79562.000 & 482 & & & & \\
\hline & Promotion & 93143.000 & 482 & & & & \\
\hline & Supervision & 130916.000 & 482 & & & & \\
\hline & Benefits & 91727.000 & 482 & & & & \\
\hline & Reward & 98097.000 & 482 & & & & \\
\hline & $\begin{array}{l}\text { Operation } \\
\text { procedures }\end{array}$ & 101396.000 & 482 & & & & \\
\hline & Co-workers & 117191.000 & 482 & & & & \\
\hline & $\begin{array}{c}\text { The nature of the } \\
\text { job }\end{array}$ & 142801.000 & 482 & & & & \\
\hline & Communication & 128708.000 & 482 & & & & \\
\hline \multirow{9}{*}{$\begin{array}{c}\text { Corrected } \\
\text { Total }\end{array}$} & Salary & 5469.519 & 481 & & & & \\
\hline & Promotion & 4865.969 & 481 & & & & \\
\hline & Supervision & 6818.996 & 481 & & & & \\
\hline & Benefits & 5227.313 & 481 & & & & \\
\hline & Reward & 5657.944 & 481 & & & & \\
\hline & $\begin{array}{l}\text { Operation } \\
\text { procedures }\end{array}$ & 3648.083 & 481 & & & & \\
\hline & Co-workers & 4347.380 & 481 & & & & \\
\hline & $\begin{array}{c}\text { The nature of the } \\
\text { job }\end{array}$ & 3808.832 & 481 & & & & \\
\hline & Communication & 4675.170 & 481 & & & & \\
\hline
\end{tabular}


University professors in Serbia $(M=12.75, S D=3.58)$ and Slovenia $(M=12.40$, $\mathrm{SD}=3.34$ ) are more satisfied with their salaries than are professors in Bosnia and Herzegovina $(M=11.80, S D=2.92)$. The results also show that professors in Serbia are more satisfied with the possibility of promotion $(M=14.21, S D=2.99)$ in comparison with professors in Bosnia and Herzegovina $(M=13.63, S D=3.06)$ and Slovenia $(M=12.50$, $S D=3.92)$. In contrast to those parameters, professors in Slovenia $(M=14.49, S D=3.03)$ are more satisfied with benefits in comparison with respondents in Bosnia and Herzegovina $(M=12.27, S D=2.98)$ and Serbia $(M=13.29, S D=3.42)$. Our results also show that professors in Serbia $(M=15.20, S D=3.09)$ and Slovenia $(M=15.83, S D=3.07)$ are more satisfied with co-workers, in comparison with professors in Bosnia and Herzegovina $(M=14.83, S D=2.69)$. Professors in Serbia $(M=17.02, S D=2.90)$ and Slovenia $(M=17.34$, $S D=2.60$ ) are also significantly more satisfied with the nature of the job in comparison with respondents in Bosnia and Herzegovina $(M=16.49, S D=2.86)$.

\subsection{Differences between job satisfaction in Serbia, Slovenia, and Bosnia and Herzegovina}

According to statistical analysis, professors in Slovenia $(M=133.03, S D=21)$ are more satisfied with their jobs compared with professors in Serbia $(M=132.84, S D=22)$ and Bosnia and Herzegovina $(M=128.09, S D=17,53)$ (Table 11).

Table 11. Job satisfaction

\begin{tabular}{|c|c|c|c|c|c|c|c|c|}
\hline & \multirow[b]{2}{*}{$\mathrm{N}$} & \multirow[b]{2}{*}{ Mean } & \multirow{2}{*}{$\begin{array}{c}\text { Std. } \\
\text { Deviation }\end{array}$} & \multirow{2}{*}{$\begin{array}{l}\text { Std. } \\
\text { Error }\end{array}$} & \multicolumn{2}{|c|}{$\begin{array}{l}\text { 95\% Confidence } \\
\text { Interval for Mean }\end{array}$} & \multirow[b]{2}{*}{ Minimum } & \multirow{2}{*}{ Maximum } \\
\hline & & & & & $\begin{array}{l}\text { Lower } \\
\text { Bound }\end{array}$ & $\begin{array}{l}\text { Upper } \\
\text { Bound }\end{array}$ & & \\
\hline Serbia & 212 & 132.8396 & 21.99338 & 1.51051 & 129.8620 & 135.8172 & 84.00 & 187.00 \\
\hline Slovenia & 151 & 133.0331 & 20.99664 & 1.70868 & 129.6569 & 136.4093 & 75.00 & 194.00 \\
\hline $\begin{array}{c}\text { Bosnia and } \\
\text { Herzegovina }\end{array}$ & 126 & 128.0873 & 17.53078 & 1.56177 & 9964 & 131.1782 & 78.00 & 171.00 \\
\hline Total & 489 & 131.6748 & 20.68476 & .93540 & 129.8369 & 133.5127 & 75.00 & 194.00 \\
\hline
\end{tabular}

Table 12. Difference in job satisfaction among university professors in Serbia, Slovenia, and Bosnia and Herzegovina

\begin{tabular}{|c|c|c|c|c|c|}
\hline & Sum of Squares & df & Mean Square & F & Sig. \\
\hline Between Groups & 2187.879 & 2 & 1093.940 & 2.573 & .077 \\
\hline Within Groups & 206607.421 & 486 & 425.118 & & \\
\hline Total & 208795.301 & 488 & & & \\
\hline
\end{tabular}

The difference in job satisfaction among university professors in Serbia, Slovenia, and Bosnia and Herzegovina is not statistically significant, $F(2.488)=-2.57, p=0.08$ (Table 12).

\section{Discussion}

Our study aimed to investigate whether the type of organizational culture has any effect on job satisfaction and whether there are any differences between Serbia, Bosnia and Herzegovina, and Slovenia. We also investigated the different dimensions of job 
satisfaction in university professors in the three countries and their correlation with different types of organizational cultures. Our results show that professors in Serbia and Slovenia have a higher level of job satisfaction in comparison with professors in Bosnia and Herzegovina. Namely, professors in Serbia and Slovenia are more satisfied with the salary, with co-workers as well as with the nature of the job in comparison with university professors in Bosnia and Herzegovina.

The analyses of results show that while there are no statistically significant differences between university professors in those three countries with regard to job satisfaction, professors in Serbia and Slovenia are more satisfied than professors in Bosnia and Herzegovina.

The most important characteristic of employees is their attitude towards work (Tsai et al. 2011; Usop et al. 2013). This attitude is called job satisfaction and can be defined as the cognitive, affective, and evaluative reactions of employees to their jobs. Our results show that the nature of the job, benefits, and chances for promotion are the main factors of job satisfaction. This statement is consistent with the results of Janićijević (2008), whose study showed that the three above-mentioned factors are the main factors of job satisfaction. In the Cameron study, job satisfaction referred to the satisfaction of faculty members with their jobs and employment in their educational institute (Cameron 1978). The concept of job satisfaction and organizational culture explored in our study has the same definition. Our results show that Power Culture, Role Culture, and People Culture significantly predict job satisfaction in university professors in the three countries we investigated.

Based on statistical analysis, we detected statistically significant differences between professors in Serbia, Slovenia, and Bosnia and Herzegovina with regard to Power Culture and Role Culture. Both types of organizational culture, Power Culture and Role Culture, were more pronounced in Slovenia in comparison with Serbia and Bosnia and Herzegovina. In their study, Dadgar et al. (2013) aimed to investigate the relationship between organizational culture, job satisfaction, organizational commitment and intention to stay at a specific organization. The results of their study that involved 385 employees of the Medical Sciences University of Zahedan, Iran, showed that adhocracy cultures and market cultures were positively and significantly correlated to satisfaction with co-workers. Their results also confirmed that successful managers can build trust between managers and workers, motivate individuals, and manage information by identifying appropriate cultures (Dadgar et al. 2013).

In some relations, those results are in correlation with our results which confirmed that professors in Bosnia and Herzegovina have the lowest level of job satisfaction in comparison with professors in Serbia and Slovenia. This situation could be a consequence of the dramatic social and educational changes which occurred in that country. Although the three countries investigated in our study did not show significant differences in the level of job satisfaction, it is clear that job satisfaction is the highest in professors in Slovenia, then in Serbia and, finally, in Bosnia and Herzegovina. In all three countries, nine dimensions of job satisfaction share a significant positive correlation, while only Power Culture is not statistically significantly correlated with job satisfaction. In all the other three types of organizational cultures, our results showed a significant negative correlation. This 
means that only Power Culture does not have a significant influence on job satisfaction in university professors included in our study.

Also, Power Culture and Role Culture were more pronounced in professors in Slovenia in comparison with professors in Serbia and Bosnia and Herzegovina. The results of our study also showed that there are significant statistical differences between Serbia, Slovenia, and Bosnia and Herzegovina with regard to the combination of nine factors of job satisfaction. The professors in Serbia and Slovenia showed significant differences, especially in five job satisfaction factors: salary, promotion, benefits, co-workers, and the nature of the job. The Serbian professors were more satisfied with the possibility of promotion in comparison with the professors in Bosnia and Herzegovina, and Slovenia. In contrast to those parameters, the professors in Slovenia were more satisfied with benefits in comparison with the respondents in Bosnia and Herzegovina, and Serbia. Generally, the professors in Bosnia and Herzegovina had the lowest level of satisfaction of all investigated dimensions of job satisfaction. According to all results presented in our study, job satisfaction did not significantly differ between any of the three investigated countries. The job satisfaction of professors is a complex concept which depends on many different variables. Ladebo and co-workers showed in their study that professional commitment significantly affects the job satisfaction of Nigerian teachers (Ladebo 2005). In a way, our results indicate that communication, as one of the most important dimensions of job satisfaction, has an impact on professor job satisfaction. The same results were confirmed in a study by De Nobile and McCormick (2008). A study by Kim showed that effective supervisory communication positively affects job satisfaction (Kim 2002), a finding that is also consistent with our results. In all such studies, researchers should pay attention to the fact that professors emphasize that both social and cultural differences between countries must be recognized (Kwong et al. 2010).

\section{Conclusion}

Our results show that professors in Serbia and Slovenia have a higher level of job satisfaction in comparison with professors in Bosnia and Herzegovina. Namely, professors in Serbia and Slovenia are more satisfied with the salary, with co-workers as well as with the nature of the job in comparison with university professors in Bosnia and Herzegovina. Based on the analyses, our results show that while there are no statistically significant differences between university professors in the three countries with regard to job satisfaction, professors in Serbia and Slovenia are more satisfied than professors in Bosnia and Herzegovina. It is very important to understand the relationships between the aspects of organizational culture and professor job satisfaction because organizational culture can be changed and improved if all university members recognize the necessity for change and work together to improve the organizational culture. Improving the organizational culture could enhance professor job satisfaction, which could, in turn, have a positive impact on the effectiveness of higher education in those three countries. Furthermore, the education systems in all three investigated countries have been facing many challenges and problems in the last few decades as a result of the direct and indirect 
impact of the transition process, leading to a decline in job satisfaction among university professors.

Therefore, investigating whether and how university culture impacts the job satisfaction of professors would be of significant importance in finding ways to increase their job satisfaction, especially now, in this time of difficulties, as well as in the future. Also, one of the most significant characteristics of this study is that similar studies have not been conducted in any of the three countries to date.

\section{Acknowledgement:}

The present study has been presented at the 12th International Conference "Economies of the Balkan and Eastern European Countries", EBEEC 2020, that has been online in Opatija, Croatia from May 29th to 31th 2020 (http://ebeec.ihu.gr/).

\section{References}

Alas, R. and Vadi, M. (2004), "The impact of organizational culture on attitudes concerning postsoviet organizations", Journal for East European Management Studies, Vol. 9, No. 1, pp. 2040.

Aoms, E.A. and Weathington, B.L. (2008), "An analysis of the relation between employee organization value congruence and Employee Attitudes", The journal of psychology, Vol. 142, No. 6, pp. 615-631,https://doi.org/10.3200/JRLP.142.6.615-632

Aydin, A., Uysal, S. and Sarier, Y. (2012), "The effect of gender on job satisfaction of teachers: A meta-analysis study", Procedia Soc Behav Sci, Vol. 46, pp. 356-362.

Behzadi, F., Shaghayegh, K.M., Somayeh, E., Hajar, C., Roshani, F. and Behzadi, F. (2012), "Relationship between job satisfaction and organizational culture in staffs and experts of physical education offices of Mazandaran Province", European Journal of Experimental Biology, Vol. 2, No. 4, pp. 1029-1033.

Bellou, V. (2010), "Organizational culture as a predictor of job satisfaction: the role of gender and age", Career Development International, Vol. 15, No. 1, pp. 4-19, https://doi.org/10.1108/13620431011020862

Bolliger, D.U. and Wasilik, O. (2009), "Factors influencing faculty with online teaching and learning in higher education", Distance Education, Vol. 30, No. 1, pp. 103-116.

Cameron, K.S. (1978), "Measuring organizational effectiveness in institutions of higher education", Administrative Science Quarterly, Vol. 23, pp. 604-632.

Chang, S. and Lee, M.S. (2007), "A study on relationship among leadership, organizational culture, the operation of learning organization and employees' job satisfaction", The Learning Organization, Vol. 14, No. 02, pp. 157, https://doi.org/10.1108/09696470710727014

Dadgar, H., Barahouei, F., Mohammadi, M., Ebrahimi, M. and Ganjali, A. (2013), "The relationship between organizational culture, job satisfaction, organizational commitment and intention to stay of health personnel's of Zahedan University of medical sciences", World Applied Sciences Journal, Vol. 21, No. 8, pp. 1220-1228.

De Nobile, J.J. and McCormick, J. (2008), "Organizational communication and job satisfaction in Australian Catholic primary schools", Educational Management Administration \& Leadership, Vol. 36, No. 1, pp. 101-122, https://doi.org/10.1177/1741143207084063

Drucker, P.F. (2007), Management challenges for the 21st century, Routledge, UK.

Du, P., Lai, M.H. and Lo, L.N.K. (2010), "Analysis of job satisfaction of university professors from nine Chinese universities", Front Educ China, Vol. 5, pp. 430-449, https://doi.org/10.3390/ijerph121012761 
Guan, X., Sun, T., Hou, Y., Zhao, L., Luan, Y.Z. and Fan, L.H. (2014), "The relationship between job performance and perceived organizational support in faculty members at Chinese universities: a questionnaire survey", BMC Med Educ, Vol. 14, pp. 50, https://doi.org/10.1186/1472-6920$\underline{14-50}$

Hanke, S.H. and Krus, N.E. (2012), World Hyperinflations, The Handbook of Major Events in Economic History, Routledge Publishing, viewed 10. January 2020, http://ssrn.com/abstract=2130109

Hofstede Insights, Compare Countries, viewed 20. December 2019, https://www.hofstedeinsights.com/models/national-culture

Janićijević, N. (2008), Organizational behavior, Data Status, Belgrade, Serbia.

Janković, A. and Jarić, I. (2009), "Conditions of Teaching Staff at the University of Belgrade: Evaluation of Teachers' Work". Philosophy and Society, Vol. 3, pp. 3-22.

Jarić, I. (2009), "Conditions for Teaching Staff at the University of Belgrade: relations with the administration", Philosophy and Society, Vol. 3, pp. 23-39.

Khalid, S., Irshad, M.Z. and Mahmood, B. (2012), "Job satisfaction among academic staff: a comparative analysis between public and private sector universities of Punjab, Pakistan", International Journal of Business and Management, Vol. 7, No. 1, pp. 126-136, https://doi.org/10.5539/ijbm.v7n1p126

Kim, S. (2002), "Participative management and job satisfaction: Lessons for management leadership", Public Administration Review, Vol. 62, No. 2, pp. 231-241, https://doi.org/10.1111/0033-3352.00173

Klassen, R.M. and Chiu, M.M. (2010), "Effects on teachers' self-efficacy and job satisfaction: Teacher gender, years of experience, and job stress", J Educ Psychol, Vol. 102, pp. 741, https://psycnet.apa.org/doi/10.1037/a0019237

Kwong, J., Wang, H. and Clifton, R.A. (2010), "Rethinking our assumptions about teachers' job satisfaction in China and the West", Australian Journal of Education, Vol. 54, No. 2, pp. 115132.

Ladebo, O.J. (2005), "Effects of work-related attitudes on the intention to leave the profession: An examination of school teachers in Nigeria", Educational Management Administration \& Leadership, Vol. 33, No. 3, pp. 355-369.

Robbins S.P. and Coulter, M. (2005), Management, Pearson Prentice Hall.

Salanova, A. and Kirmanen, S. (2010), "Employee satisfaction and work motivation", Bachelor's Thesis Business Management, March, 2010.

Scott-Findlay, S. and Estabrooks, C.A. (2006), "Mapping the organizational culture research in nursing. In: A literature review", Journal of Advanced Nursing, Vol. 56, No. 5, pp. 498-513.

Spector, P.E. (1985), "Measurement of human service staff satisfaction: Development of the job satisfaction survey", American Journal of Community Psychology, Vol. 13, pp. 693-713, https://doi.org/10.1007/bf00929796

Spector, P.E. (1997), Job satisfaction: Application, assessment, causes, and consequences, Thousand Oaks, CA.: Sage, http://dx.doi.org/10.4135/9781452231549

Syed, A.A.S.G., Bhatti, N., Michael, S., Shaikh, F.M. and Shah, H. (2012), "Job satisfaction of faculty members of universities in Pakistan: A case study of university of Sindh-Jamshoro", Modern Applied Science, Vol. 6, No. 7, pp. 89-95.

Trivellas, P. and Dargenidou, D. (2009), "Leadership and service quality in higher education: the case of the Technological Educational Institute of Larissa", International Journal of Quality and Service Sciences, Vol. 1, No. 3, pp. 294-310, dx.doi.org\%2F10.1108\%2F17566690911004221

Tsai, Y. (2011), "Relationship between Organizational Culture, Leadership Behavior and Job Satisfaction", BMC Health Services Research, Vol. 11, p. 98. 
Usop, A.M., Askandar, D.K. and Langguyuan-Kadtong, M. (2013), "Work performance and job satisfaction among teachers", Int J Humanit Soc Sci, Vol. 3, pp. 245-252.

Watson, B., Clarke, C., Swallow, V. and Forster, S. (2005), "Exploratory factor analysis of the research and development culture index among qualified nurses", Journal of Clinical Nursing, Vol. 14, pp. 1042-1047, https://doi.org/10.1111/j.1365-2702.2006.01265.x

Yuan, L., Xie, C. and Xie, F.S. (2006), "An investigation and analysis of the teachers job satisfaction in higher education", J Educ Sci Hunan Normal Univer, Vol. 3, pp. 103-106.

Zamini, S. and Hosseini Nasab, D. (2009), "A study of relationship between organizational culture and job satisfaction among professoriates and employees in Tabriz University", Organizational Culture Management, Vol. 7, No. 20, pp. 121-130. 